Bei Behandlung von Pseudarthrosen sollte auf jeden Fall die Fraktur stabilisiert werden, wenn mangelnde Stabilität die Ursache war.

Bei Infektionen wurden die Metalle entfernt und nach Abklingen der Infektion eine erneute Osteosynthese durchgeführt. In 3 Fällen wurde zu früh belastet. In 4 Fällen waren biologische Frakturen die Ursache einer Pseudarthrosenbildung.

\title{
322. Gefahren der Osteosynthese bei Handverletzungen
}

\section{A. Pannike* und D. Ventelmanta-Tübingen}

\section{Risks of Internal Fixation in Hand Injuries}

Summary. The scale of recommended lines of treatment for hand fractures still ranges from external immobilisation via minimal operative intervention to stable internal fixation of fragments intended to ensure early mobilisation of all articulations without P. o. P. On the basis of a large patient material the possibilities and limitations of the osteosynthesis procedures commonly used in hand surgery are compared, with special consideration of the possibilities, limitations and dangers with the use of the small-fragment set of instruments of the Swiss AO. The results are based on over 6 years' clinical and experimental work with these instruments. It is emphasised that the principal dangers of operative as well as conservative hand fracture treatment-pseudarthrosis, infection, permanent loss of functioncan be lessened or prevented only by careful assessment of indication, critical evaluation of the general situation, especially the condition of the soft tissues, and accurate knowledge of the possibilities and limitations of the chosen procedure.

Zusammenfassung. Die Skala empfohlener Behandlungsrichtlinien reicht bei Knochenbrüchen an der Hand noch immer von der äußeren Ruhigstellung über den operativen Minimaleingriff bis zur stabilen inneren Fixation der Fragmente, welche die gipsfreie Frühmobilisation aller Gelenke gewährleisten soll.

Anhand eines eigenen großen Krankengutes werden die Möglichkeiten und Grenzen der in der Handchirurgie üblichen Osteosyntheseverfahren vergleichend dargelegt. Insbesondere wird hier darauf Wert gelegt, die Möglichkeiten wie die Grenzen und Gefahren bei Anwendung des Kleinfragment-Instrumentariums der Schweizer AO darzustellen. Diese Erfahrungen gründen sich auf eine mehr als 6 jährige klinische und experimentelle Arbeit mit dem genannten Instrumentarium.

Es wird nachdrücklich darauf hingewiesen, daß die Hauptgefahren der operativen wie der konservativen Knochenbruchbehandlung an der Hand: die Pseudarthrose, der Infekt und der bleibende Funktionsverlust, nur bei sorgfältiger Indikationsstellung, kritischer Beurteilung der Gesamtsituation und vor allen Dingen der Weichteilsituation wie der exakten Kenntnis der Möglichkeiten und Grenzen eines gewählten Verfahrens vermindert oder vermieden werden können.

\section{Offene oder geschlossene Osteosynthese?}

\section{G. KüNTsCHER-Flensburg}

\section{Open or Closed Osteosynthesis?}

Summary. The most important question in osteosynthesis is whether it should be done open or closed. Statistics show that all serious complications, such as 